\title{
EFFECTIVENESS OF AUDIOVISUAL-BASED TRAINING ON BASIC LIFE SUPPORT KNOWLEDGE OF STUDENTS IN BENGKULU
}

\author{
Ida Rahmawati'), Dwi Putri Sulistya Ningsih²) \\ 1)Emergency Nursing Department, Study Program of Nursing Science, \\ School of health sciences Tri Mandiri Sakti Bengkulu, Indonesia \\ 2)Public Health Study Program School of health sciences Tri Mandiri \\ Sakti Bengkulu, Indonesia
}

\begin{abstract}
Background: Emergencies can occur around us. Basic knowledge about saving lives is needed to reduce the death rate. Basic Life Support (BHD) is an emergency treatment effort for cardiac arrest done by everyone, including students. This study aimed to determine the effect of audiovisual-based training on Nursing Students Basic Life Support (BHD) knowledge in Bengkulu City.

Subject and Method: This was a quasi-experiment study with no control group. The study was conducted at school of science Tri Mandiri Sakti, Bengkulu, Indonesia. A sample of 64 nursing students was selected by total sampling. The intervention group was carried out by viewing the BHD simulation video via the LCD. Knowledge was measured by questionnaire. Knowledge level before and after treatment were tested by t-test.

Result: Mean score of knowledge after training basic life support (Mean = 74.53; $\mathrm{SD}=$ 13.444; 95\% CI = 27.502) was higher than before training (Mean $=50.47 ; \mathrm{SD}=11,468$; $95 \% \mathrm{CI}=20,623)$, and it was statistically significant $(\mathrm{p}<0.001)$.

Conclusion: Audiovisual-based training is effective in improving knowledge of students about basic life support.
\end{abstract}

Keywords: audio visual, basic life support, knowledge.

Correspondence:

Ida Rahmawati, Emergency Nursing Department, Nursing Science Study Program, School of health sciences Tri Mandiri Sakti Bengkulu, Indonesia. Email: idarahmawati1608@gmail.com. Mobile: +62 852-6693-5180.

The $7^{\text {th }}$ International Conference on Public Health Solo, Indonesia, November 18-19, $2020 \mid 156$ https://doi.org/10.26911/the7thicph.02.45 